\title{
INPUTS OF NITROGEN AND PHOSPHORUS TO ESTUARIES OF NORTHEASTERN BRAZIL FROM INTENSIVE SHRIMP FARMING
}

\author{
LACERDA, L.D. \\ Instituto de Ciências do Mar (LABOMAR), Universidade Federal do Ceará \\ Av. Abolição 3207, Fortaleza, CE, Brasil. Idrude@pgcmt.labomar.ufc.br
}

\begin{abstract}
Lacerda, L.D. 2006. Inputs of Nitrogen and Phosphorus to Estuaries of Northeastern Brazil from Intensive Shrimp Farming. Braz. J. Aquat. Sci. Technol. 10(2):13-27. ISSN 1808-7035. Intensive shrimp aquaculture has increased by about $20 \%$ per year during the last decade along the semi-arid NE coast of Brazil due to the optimal climate and environmental setting. Emissions of $\mathrm{N}$ and $\mathrm{P}$ from this activity to 16 estuaries along the coast of Ceará and Rio Grande do Norte states, NE Brazil, where about $80 \%$ of the shrimp farming area of the country is located, showed that intensive

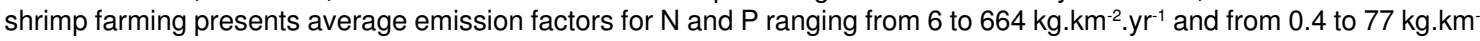
${ }^{2} . \mathrm{yr}^{-1}$, respectively. These emission factors resulted in total annual emissions of 9 to $485 \mathrm{t}^{\mathrm{yr}} \mathrm{r}^{-1}$ and 0.7 to $35 \mathrm{t}$. $\mathrm{yr}^{-1}$, for $\mathrm{N}$ and $\mathrm{P}$ respectively. Larger loads occurred at the Jaguaribe River (Ceará State) and the Açu River (Rio Grande do Norte State). Intensive shrimp farming is the major relative contributor of $\mathrm{N}$ to the Jaguaribe (CE) $(41 \%)$ and Açu (RN) $(63 \%)$ basins. Also at the Guamaré basin (RN) it contributes with $26 \%$ of the total $N$ load. Contribution of $\mathrm{P}$ from intensive shrimp farming is relatively small varying from $<5 \%$ in most basins to a maximum contribution of $13 \%$ at the Açu basin (RN). Although the contribution of intensive shrimp farming relative to agriculture and husbandry is small in most of the studied areas, the location of farms adjacent to estuaries makes possible direct inputs to waters, while most other emissions go firstly to soils before eventually being transported to surface waters.
\end{abstract}

Key words: Nitrogen, phosphorus, estuaries, shrimp farming, northeastern Brazil.

\section{INTRODUCTION}

Many estuaries are submitted to environmental impacts resulting from the excess of nutrient loads from anthropogenic activities installed at their watersheds. These include changes in community structure and food webs, harmful algal blooms, excessive seaweed and epiphyte growth, low oxygen level, and reduced biodiversity (Bricker et al., 1999; 2003). Most of these impacts result from a complex chain of events varying in space and time, but that can be attributable to an ultimate pressure: the accumulation of excess nitrogen and phosphorus in fluvial water in its way to the ocean (NRC, 2000; Tappin, 2002).

Primary production and the eventual onset of the eutrophication process are ultimately related to the ecological response to excess nutrient loads, in particular of nitrogen, in a manner similar to the correlation between the actual nutrient concentrations in water (Rosenberg et al., 1990; Boynton et al., 1995; Brunner, 1998; EPA, 2002; NRC, 2000). Therefore, the use of nutrient loads instead of concentrations, particularly in areas were detailed studies on nutrient concentrations are unavailable, such as in the semi-arid coast of NE Brazil, may turn into a satisfactory approach to evaluate the sensibility of estuarine systems to further introduction of anthropogenic effluents.

Many estuaries of the semi-arid coast of NE Brazil where intensive shrimp farming takes place, also receives nutrients form other anthropogenic sources, among them the disposal of untreated sewage; solid wastes and waste waters, urban runoff, husbandry and the use of fertilizers and other chemicals in agriculture. Industrial effluents are a minor source of nutrients along this part of the Brazilian coast whereas large metropolitan areas lack aquaculture activities. Apart from the anthropogenic sources, natural processes' contributions to the nutrient loads are atmospheric deposition and soil runoff.

Shrimp aquaculture has increased by about $20 \%$ per year during the last decade along the NE coast of Brazil due to the optimal climate and environmental setting. Shrimp farms in Brazil occupied less than 100 ha in 1998. By 2003, however, farm area has increased to over 14,000 ha, about 11,500 ha located along the NE coast, about 7,900 ha located along the semi-arid coast of Ceará and Rio Grande do Norte States (ABCC, 2003). Worldwide the activity has been blamed to cause several environmental impacts associated with the emission of large amounts of $\mathrm{N}$ and $\mathrm{P}$ to estuarine waters (Twilley et al., 1999; Burford et al., 2003). Experimental data from $\mathrm{N}$ and $\mathrm{P}$ emissions form shrimp farms in Australia varied from 290 and $16 \mathrm{~kg}$ ha $^{-1} \cdot \mathrm{yr}^{-1}$, respectively (Jackson et al., 2003; Burford et al., 2003). In the Gulf of California, Mexico, annual input of $\mathrm{N}$ and $\mathrm{P}$ from shrimp farms reaches 112 and $32 \mathrm{~kg}$.ha-1 ${ }^{-1}$, respectively (PaezOsuna et al., 1999; 2003). However, few studies have compared shrimp farming $\mathrm{N}$ and $\mathrm{P}$ emissions with other 
anthropogenic and natural sources in a given area making difficult the associations between shrimp farm effluents and eutrophication to be revealed (Lacerda et al., 2006).

In the present study a comparison is given, based on an emission factor approach, of the annual emissions of $\mathrm{N}$ and $\mathrm{P}$ from intensive shrimp farming and other different anthropogenic sources and natural processes to 16 estuaries along the coast of NE Brazil, where about $80 \%$ of the shrimp farming area of the country is located.

\section{MATERIAL AND METHODS}

\section{Study areas}

The Northeastern region is the largest producer of cultivated shrimp in Brazil, with about 11,500 ha of shrimp ponds and average productivity of about 6.2 t.ha $\mathrm{t}^{-1} \cdot \mathrm{yr}^{-1}$ and a total annual production of about 66,000 tons (ABCC, 2003). The activity is developed in estuarine areas of low urban and no industrial development, seeking good environmental conditions, particularly of water quality for its proper development. However, most urban wastes are not treated, while agriculture and husbandry have recently developed fast along the coastal region. Therefore, scattered data already suggest that some of these areas are showing signs of incipient eutrophication, potentially threatening the activity (Guedes, 2003).

Figure 1 shows the location of the 16 estuarine areas studied. The lower basins of the 16 rivers are located within the "Tabuleiros Costeiros do Nordeste" formation characterized by Tertiary and Quaternary sediments forming coastal plains constituted by sandy soils closer to the coast and yellow-red latosols (mostly oxisols) inland. Small stretches of alluvial eutrophic soils occur along river valleys (Pedreira, 1971; RADAM-BRASIL, 1981; Silva \& Mendonça, 1989; Silva, 1996; Hidroservice, 1998; IDEMA, 1999a,b; Lima et al., 2000). Natural vegetation in most of the area has been converted to subsistence, non-mechanized agriculture and extensive husbandry. Major cultures in the sandy soils are coconut, cashew nut and banana, whereas latosols are used mostly for sugar cane and pasture. Population density is generally low and concentrated in small towns close to the sea. Table 1 shows the major environmental characteristics of the 16 estuaries studied. Rainfall varies from $1,250 \mathrm{~mm} \cdot \mathrm{yr}^{-1}$ at the Guaraíras basin to 550 mm.yr ${ }^{-1}$ at the Açu Basin. The 16 estuarine systems differ by a factor of 2 to 20 in basin area, from the larger

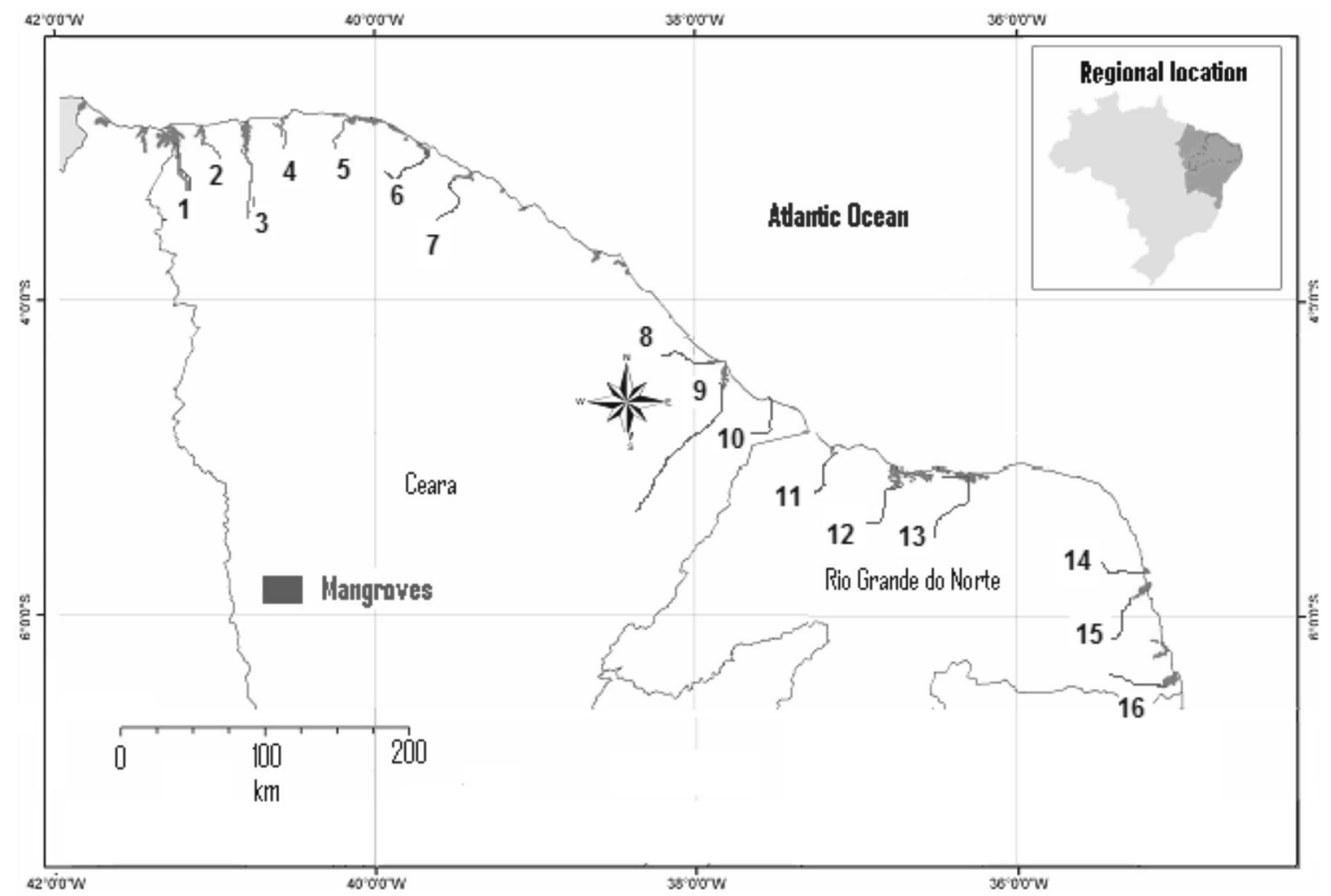

Figure 1 - Map showing the locations of the 16 studied river basins in NE Brazil. 1. Timonha, 2. Coreaú, 3. Acaraú, 4. Aracatiaçu, 5. Aracatimirim, 6. Curu, 7. Mundaú, 8. Pirangi, 9. Jaguarabe, 10. Icapuí, 11. Apodi, 12. Açu, 13. Guamaré, 14. Ceará Mirim, 15. Guaraíras, 16. Curimataú. 
Coreaú $\left(4,680 \mathrm{~km}^{2}\right)$ basin to the smaller Ceará Mirim basin $\left(200 \mathrm{~km}^{2}\right)$. Shrimp far area also vary largely by a facto of 40 from the Açu basin $(1,679$ ha) to the smaller Ceará Mirim with only 30 ha of shrimp ponds (Table 1 ).

\section{Emission factors approach}

Nutrient load to non-industrialized coastal watersheds is mostly from diffuse sources and therefore, is a difficult variable to be directly measured, so indirect approaches based on emission factors and inventories of natural processes and anthropogenic activities dimensions are the most applicable strategy for their estimation (Tappin, 2002). Estimates of nutrient loads to a given estuary are achieved by using emission factors based on production/consumption parameters of the different anthropogenic sources and the chemical balance of natural processes (Nriagu \& Pacyna, 1988; Howarth et al., 1996; Howarth, 1998). Most necessary variables can be estimated from surveys and inventories of these activities, such as population parameters, urban and rural areas per basin, agriculture production and fertilizer use, among others. Emission factors have been successfully used to estimate nutrient and pollutant load at the local (e.g. Barcellos \& Lacerda, 1994; Binner et al., 1996; Marins et al., 1998; 1999); regional (Lacerda et al., 1995; 2006; Howarth et al., 1996; Lacerda \& Marins, 1997; Howarth, 1998; NRC, 2000; Vaisman \& Lacerda, 2003); and global (Nriagu \& Pacyna, 1988; Nriagu, 1989; Pirrone et al., 1996; 1998) levels and have been adopted as standard methodology by various environmental agencies (EEA, 1999; EPA, 2002). In general, emission factors (EF's) used in this study were those available in the literature for each activity or process. However, all EF's were adapted to local conditions whenever necessary. For example, wastewater production per inhabitant is generally calculated based on water consumption parameters typical of urban areas. However, under the semi-arid condition of most of the studied basins, these factors were corrected by the actual water consumption rate of the population of each basin (Döll \& Hauschild, 2002). Similarly, fertilizer utilization, shrimp farming technology and other agricultural parameters used in the present study were those of the actual sites. General global

Table 1 - Major environmental characteristics and shrimp production statistics of the studied estuaries along the Northeastern Brazilian coast.

\begin{tabular}{lcccc}
\hline \hline Estuary & $\begin{array}{c}\text { Lower basin } \\
\text { area }\left(\mathrm{km}^{2}\right)^{1,2}\end{array}$ & $\begin{array}{c}\text { Annual average } \\
\text { rainfall }(\mathrm{mm})^{1}\end{array}$ & $\begin{array}{c}\text { Population } \\
\text { (inhabitants) }\end{array}$ & $\begin{array}{c}\text { Shrimp farm area } \\
\text { in 2003 (ha) }\end{array}$ \\
\hline Timonha (CE) & 615 & 1,120 & 26,084 & 147 \\
Acaraú (CE) & 3,000 & 1,000 & 132,082 & 743 \\
Coreaú (CE) & 4,680 & 1,100 & 123,913 & 439 \\
Aracatiaçú (CE) & 1,580 & 830 & 32,333 & 62 \\
Aracatimirim (CE) & 740 & 1,140 & 30,347 & 58 \\
Curu (CE) & 600 & 1,240 & 53,003 & 110 \\
Mundaú (CE) & 2,135 & 1,590 & 138,896 & 42 \\
Pirangi (CE) & 1,627 & 910 & 42,343 & 90 \\
Jaguaribe (CE) & 1,735 & 900 & 79,832 & 1,260 \\
Icapui (CE) & 430 & 950 & 16,052 & 59 \\
Apodi (RN) & 975 & 700 & 244,600 & 874 \\
Açu (RN) & 950 & 550 & 58,900 & 1,680 \\
Guamaré (RN) & 550 & 600 & 9,900 & 414 \\
Ceará Mirim (RN) & 200 & 900 & 19,600 & 30 \\
Guaraíras (RN) & 325 & 1,250 & 59,100 & 1,070 \\
Curimataú (RN) & 300 & 1,150 & 34,800 & \\
\hline \hline
\end{tabular}

1- Hydroservice (1998); IDEMA (1999a; 1999b). 2 - Maia (2004). 3 - IBGE (2003a). 4. ABCC (2003). 
emission factors were used when data for the actual site were unavailable.

\section{RESULTS AND DISCUSSION}

\section{Natural emissions: Soil runoff}

Soil loss and atmospheric deposition are the two major natural processes contributing with $\mathrm{N}$ and $\mathrm{P}$ to the studied basins. Soil loss is highly increased by agriculture and depends on soil type and climate. Losses from agricultural land can range from 116 to

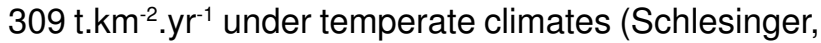
1997; Gouldie, 1987) to 60 to $760{\mathrm{t} . \mathrm{km}^{-2} . \mathrm{yr}^{-1} \text { in tropical }}^{2}$ regions and averages about $130 \mathrm{t} . \mathrm{km}^{-2} . \mathrm{yr}^{-1}$ for low declivity areas with lack of mechanized agriculture (Greenland \& Lal, 1977), such as the coastal plains of northeastern Brazil. Based on a review on soil loss rates for soil types and environmental settings similar to those found in our study area, Gouldie (1987) also proposed a similar average soil loss rate of $128 \mathrm{t}_{\mathrm{km}} \mathrm{km}^{-2} \mathrm{yr} \mathrm{r}^{-1}$, which will be then used for the calculations in the present study.

Emissions of $\mathrm{N}$ and $\mathrm{P}$ through soil loss depend on their concentrations in each soil type. Concentrations of $\mathrm{N}$ and $\mathrm{P}$ in soils of the region studied are available for many NE Brazilian coastal basins and soil types (Silva, 1996; Ramalho \& Sobrinho, 2001; Ramalho et al., 2001) and were used to estimate soil $\mathrm{N}$ and $P$ loss to rivers. These concentrations range from 500 to $900 \mathrm{mg} . \mathrm{g}$ ${ }^{1}$ and from 100 to $500 \mathrm{mg} \cdot \mathrm{g}^{-1}$ for $\mathrm{N}$ and $\mathrm{P}$ respectively, depending on soil type. Finally, the estimates of $\mathrm{N}$ and $\mathrm{P}$ losses were corrected taking into consideration the retention capacity for $\mathrm{N}$ and $\mathrm{P}$ of the soil, which also considered that part of the $\mathrm{N}$ emissions can be directly transferred to the atmosphere through denitrification and dissimilatory reduction of nitrates under sub-oxic conditions in waterlogged soils (Burford et al., 2003). For $\mathrm{P}$, however, most of it can be transferred to rivers associated with the particulate load and eventually to coastal areas (NRC, 2000). Retention rates of $N$ and $P$ for agriculture soils have been reported as $70 \%$ and 65 $\%$ for $\mathrm{N}$ and $\mathrm{P}$ respectively (Malavolta \& Dantas, 1980; Silva, 1996). Altogether, table 2 presents the estimates of $\mathrm{N}$ and $\mathrm{P}$ emissions to surface waters of the 16 basins studied based on the parameters described above. Soil type and basin area were considered the two major factors controlling nutrient emissions. Alluvial and Cambisol are the richer soil units regarding $\mathrm{N}$ and $\mathrm{P}$ concentrations, followed by latosols, solonetz and quartz sands.

Range of $\mathrm{N}$ emissions from soil loss under temperate climate and non-mechanized agriculture are

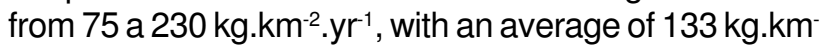
${ }^{2} . \mathrm{yr}^{-1}$ (Howarth et al., 1996; Howarth, 1998), whereas $\mathrm{P}$ emissions range from 5 to $50 \mathrm{~kg} \cdot \mathrm{km}^{-2} \cdot \mathrm{yr}^{-1}$ (Howarth et al., 1996; Valigura et al. 2000) and up to $230 \mathrm{~kg}^{\mathrm{km}} \mathrm{km}^{-2} \mathrm{yr}$ 1 in the Amazon Basin (Howarth et al., 1995). Losses of $\mathrm{N}$ and $\mathrm{P}$ per unit of area vary little among the studied basins and are in general within the lower range reported by the above-mentioned authors for mechanized agriculture (Lacerda et al., 2006). However, total emissions vary widely depending on basin size. Emissions of $\mathrm{N}$ vary from 223.4 t.yr ${ }^{-1}$ in the largest Coraú basin to 13.0 t.yr $^{-1}$ in the smallest Ceará Mirim. Emissions of $\mathrm{P}$ vary from 201.6 t.yr ${ }^{-1}$ in the Coreaú basin to 2.6 t.yr $^{-1}$ in the Ceará Mirim.

\section{Natural emissions: Atmospheric deposition}

Atmospheric deposition is a function of the basin area, the annual rainfall and the concentration of $\mathrm{N}$ and $P$ in the bulk deposition (dry and wet). The fraction of the deposition eventually reaching surface waters will also depend on the retention rate of the atmosphericderived N and P in soils (Golley et al., 1978; Johnson \& Lindberg, 1998; Silva Filho et al., 1998). Along the Brazilian coast deposition rates of these nutrients also vary depending on the degree of urbanization and industrialization of the specific sector of the littoral. Along the Brazilian coast, total $\mathrm{N}$ and $\mathrm{P}$ atmospheric deposition ranges from 80 to $300 \mathrm{mgN} \cdot \mathrm{m}^{-2}$.yr-1, and 4 to $10 \mathrm{mgP.m}$ ${ }^{2}$.yr ${ }^{-1}$, over pristine and heavy industrialized sites, respectively and with an annual rainfall of about 1,000 mm (Silva Filho et al., 1998; Mello, 2001; 2003). These ranges of values are similar to those found for other coastal areas in the world under similar development conditions (Schlesinger et al., 1982; Johnson \& Lindberg, 1998; Brunner, 1998; Tan \& Wong, 2000). Taking into consideration the local low level of industrialization and urbanization we used as best average estimate 100 and $8 \mathrm{mg} \cdot \mathrm{m}^{-2} \cdot \mathrm{yr}^{-1}$, for $\mathrm{N}$ and $\mathrm{P}$ respectively, which are similar to the averages reported by other authors for natural or low-developed areas (Golley et al., 1978; Burns, 2004). The estimated deposition rates were corrected for the actual annual precipitation of each basin and the average soil retention rates observed for these two nutrients. Burns (2004) estimated an average of $63 \%$ atmospheric $\mathrm{N}$ retention based on results from eight Mid West USA basins. Golley et al. (1978) reported $70 \%$ retention of atmospheric $P$ in soils in the Central American coast. In coastal Brazilian soils retention rates of $\mathrm{N}$ and $\mathrm{P}$ are similar to those (about $65 \%$ and $70 \%$ for $\mathrm{N}$ and $\mathrm{P}$, respectively) (Malavolta \& Dantas, 1980; Silva et al., 2000) and these figures are used in the present study. The fraction retained in soils, however, will be included in the calculation of inputs from soil runoff, since atmospheric derived $\mathrm{N}$ and $\mathrm{P}$ make up part of their soil concentrations.

Inputs to estuaries from the atmosphere per unit of area estimated using the parameters above are 35 and $5.6 \mathrm{mg} \cdot \mathrm{m}^{-2} \cdot \mathrm{yr}^{-1}$ for $\mathrm{N}$ and $\mathrm{P}$, respectively. As 
expected, total loads from atmospheric deposition resulted highly influenced by the basin area. The largest basin of the Coreaú estuary receives 51.1 t.yr $^{-1}$ and 4.1 t.yr $r^{-1}$ of $N$ and $P$, respectively, whereas the smallest Ceará Mirim basin receives 7 and 0.5 t.yr $^{-1}$ of $\mathrm{N}$ and $\mathrm{P}$, respectively (Table 2 ).

Notwithstanding the differences in $\mathrm{N}$ and $\mathrm{P}$ concentrations in soil types and in the atmospheric deposition, basin area is the most important parameter controlling the natural loads of $\mathrm{N}$ and $\mathrm{P}$ to the basins studied. As expected, these loads are much smaller than those reported for more urbanized sites along the Brazilian coast (Mello, 2001; 2003), but are similar to those estimated for pristine environments (Golley et al., 1978; Burns, 2004).

\section{Anthropogenic emissions of $N$ and $P$ to the lower basins of the studied rivers}

The most important anthropogenic sources of $\mathrm{N}$ and $P$ in the studied areas are agriculture, husbandry and aquaculture, urban wastewaters, disposal of solid wastes and urban runoff. Their relative contribution varies depending on the degree of urbanization, population and extension of agricultural lands. Invariably, none of these effluents receive any treatment before being released into the environment along this area of the Brazilian coast.

\section{Agriculture}

Leaching of agricultural soils has caused eutrophication in many water systems, from small catchments under subsistence agriculture to larger basins receiving effluents from mechanized agriculture, such as the Gulf of Mexico Basin receiving Mississippi River inputs (Rabalais, 2002). The fraction of $\mathrm{N}$ and $\mathrm{P}$ applied as fertilizers lost from agriculture soils range from 10 to $40 \%$ and 25 to $80 \%$ for clayey and sandy soils respectively (Howarth et al., 1996). Emission factors for $\mathrm{N}$ and $\mathrm{P}$ from agriculture soils are available but mostly restricted to mechanized, large-scale agriculture and can reach $200 \mathrm{~kg} \cdot \mathrm{km}^{-2} \cdot \mathrm{yr}^{-1}$ (Sharpley \& Syers, 1979; Sharpley \& Rekolainen, 1997; Sharpley \& Tunney, 2000). Unfortunately however, these emission factors cannot be applied to the agriculture practices taking place in our sites.

Table 2 - Estimates of $\mathrm{N}$ and $\mathrm{P}$ inputs (t.yr-1) from natural sources to the studied estuaries along the Northeastern coast of Brazil.

\begin{tabular}{|c|c|c|c|c|c|c|}
\hline \multirow[t]{2}{*}{ Estuarine basin } & \multicolumn{2}{|c|}{ Soil runoff ${ }^{1,4}$} & \multicolumn{2}{|c|}{$\begin{array}{l}\text { Atmospheric } \\
\text { deposition }\end{array}$} & \multicolumn{2}{|c|}{ Total natural input } \\
\hline & $\mathbf{N}$ & $\mathbf{P}$ & $\mathbf{N}$ & $\mathbf{P}$ & $\mathbf{N}$ & $\mathbf{P}$ \\
\hline Timonha (CE) & 36.4 & 34.9 & 6.9 & 0.6 & 43.3 & 35.5 \\
\hline Acaraú (CE) & 189.6 & 174.8 & 27.5 & 2.2 & 217.1 & 177 \\
\hline Coreaú (CE) & 223.4 & 201.6 & 51.1 & 4.1 & 274.5 & 205.7 \\
\hline Aracatiaçú (CE) & 103.0 & 95.4 & 13.1 & 1.1 & 116.1 & 96.5 \\
\hline Aracatimirim (CE) & 48.0 & 39.1 & 8.4 & 0.7 & 56.4 & 39.8 \\
\hline Curu (CE) & 41.9 & 26.6 & 7.6 & 0.6 & 49.5 & 27.2 \\
\hline Mundaú (CE) & 147.3 & 119.8 & 29.0 & 2.3 & 176.3 & 122.1 \\
\hline Pirangi (CE) & 95.4 & 25.6 & 14.7 & 1.2 & 110.1 & 26.8 \\
\hline Jaguaribe (CE) & 123.6 & 45.4 & 19.8 & 1.6 & 143.4 & 47 \\
\hline Icapui (CE) & 26.8 & 7.9 & 4.1 & 0.3 & 30.9 & 8.2 \\
\hline Apodi (RN) & 76.0 & 55.6 & 24.0 & 1.6 & 100 & 57.2 \\
\hline Açu (RN) & 93.8 & 29.4 & 17.0 & 1.2 & 110.8 & 30.6 \\
\hline Guamaré (RN) & 29.3 & 5.9 & 12.0 & 0.7 & 41.3 & 6.6 \\
\hline Ceará Mirim (RN) & 13.0 & 2.6 & 7.0 & 0.5 & 20 & 3.1 \\
\hline Guaraíras (RN) & 21.2 & 10.8 & 14.0 & 1.2 & 35.2 & 12 \\
\hline Curimataú(RN) & 28.0 & 14.0 & 12.0 & 1.1 & 40 & 15.1 \\
\hline
\end{tabular}

1- From Table 2. 2 - Average $\mathrm{N}$ and $\mathrm{P}$ bulk atmospheric deposition (100 and $8.0 \mathrm{mg} \cdot \mathrm{m}^{-2} \cdot \mathrm{yr} \mathrm{r}^{-1}$, respectively), based on concentrations in bulk atmospheric deposition from Mello $(2001 ; 2003)$ and Silva Filho et al. (1998). 3 - Basin area and annual rainfall from table 1.4 - Soil retention rates of $65 \%$ and $70 \%$ for $\mathrm{N}$ and $\mathrm{P}$, respectively, after Malavolta and Dantas (1980) and Silva (1996). 
For non-mechanized agriculture average loss rates of $\mathrm{P}$ are in general much lower, $\mathrm{N}$ losses, however, are similar and are highly dependent on crop type (Silva et al., 2000). Results obtained under this type of agriculture along the Brazilian coast provide loss rates relative to the amount of fertilizer applied varying from 6 to $20 \%$ for $\mathrm{P}$ and from 26 to $32 \%$ for N (Malavolta \& Dantas, 1980; CFSEMG, 1989; Silva et al., 2000). The crop type also influences the loss rate of nutrients, since different cultures require different amount of fertilizer application. Table 3 summarizes the typical quantities of fertilizers used in agriculture in the northeastern Brazilian coastal region. Demands for $\mathrm{N}$ fertilization are particularly high for sugar cane (90 to $\left.275 \mathrm{~kg}^{\mathrm{h}} \mathrm{ha}^{-1}\right)$, sweet potatoes (40 - $\left.140 \mathrm{~kg}^{-\mathrm{ha}^{-1}}\right)$, and citrics (120 - 180 $\left.\mathrm{kg} \cdot \mathrm{ha}^{-1}\right)$, for example. Whereas for $\mathrm{P}$, particularly demanding cultures are beans and citrics $(30-60 \mathrm{~kg}$.ha$\left.{ }^{1}\right)$, fruits $\left(12-20 \mathrm{~kg}^{-\mathrm{ha}^{-1}}\right)$ and corn $\left(40-70 \mathrm{~kg} \cdot \mathrm{ha}^{-1}\right)$ (Agrobyte, 2003; EMBRAPA, 2003; SEAGRI, 2003; CPAA, 2003). Major $N$ and $P$ losses from these cultures are from sugar cane and citrics $(26-32 \%$ for $\mathrm{N}$ and $6-$ $20 \%$ for $\mathrm{P}$ ), followed by coconut, corn and beans (16$25 \%$ for N and $6-20 \%$ for P) (Malavolta \& Dantas,
1980; FSEMG, 1989). The estimated amount of nutrients loss in each basin is a function of these differences in culture type and their relative area of cultivation. As a result, the relatively small Curimataú basin (300 ha) receives more $\mathrm{N}$ from agriculture $\left(749 \mathrm{t}_{\text {. }} \mathrm{yr}^{-1}\right)$, due to the dominance of sugar cane, than the larger Açu basin

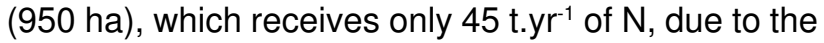
relatively small cultured area and less- $\mathrm{N}$ demanding culture types typical of this basin (Table 4).

\section{Husbandry}

Nutrients emitted from husbandry practices are released to soils as animal excretes and their concentrations will depend on the concentrations found in animal feed and on the different animal types grown in a given region. According to Boyd (1971) and Esteves (1988), average amounts of excrete ranges from 10 kg.animal ${ }^{-1}$.day ${ }^{-1}$, for cows and horses, to 2.5 and 1.0 and $0.18 \mathrm{~kg}$.animal ${ }^{-1}$. day ${ }^{-1}$, for pigs and sheep, and poultry, respectively. Nitrogen and $\mathrm{P}$ concentrations in animal excrete vary little from $0.6 \%$ for cows and horses and $0.5 \%$ for pigs and sheep for $\mathrm{N}$; and $0.35 \%, 0.3 \%$ and $0.5 \%$ of $P$ for cows and horses, pigs and sheep

Table 3 - Amount of $\mathrm{N}$ and $\mathrm{P}$ as fertilizer for the different cultures in the studied region and their respective loss rates.

\begin{tabular}{lcccc}
\hline Crop & Fertilizer $\left(\mathrm{kg} \cdot \mathrm{ha}^{-1}\right)$ & & Loss (\%) & \\
\hline Sugar cane & $\mathrm{N}$ & $\mathrm{P}$ & $\mathrm{N}$ & $\mathrm{P}$ \\
Cashew & $90-275^{1.2}$ & $20-40^{1.2}$ & $26-32^{8}$ & $6-20^{8}$ \\
Cotton & $20^{1}$ & $30^{1}$ & $20^{8}$ & $25^{8}$ \\
Beans & $22^{1,2}$ & $12^{1,2}$ & $16^{8}$ & $6^{8}$ \\
Coconut & $0-20^{5.6}$ & $60^{3}$ & $16-25^{11}$ & $0.7-1.4^{11}$ \\
Cassava & $40^{5}$ & $20^{5}$ & $25^{12}$ & $20^{12}$ \\
Corn & $0-40^{3.4}$ & $15-60^{3.4}$ & $25^{12}$ & $20^{12}$ \\
Banana & $20-60^{6.7 .8}$ & $40-70^{7.8}$ & $26-32^{8}$ & $6-20^{8}$ \\
Mango & $22^{2}$ & $12^{2}$ & $16^{13}$ & $6^{13}$ \\
Melon & $40^{9}$ & $20^{9}$ & $16^{13}$ & $6^{13}$ \\
Sweet potatoes & $100^{9}$ & $30^{9}$ & $20^{12}$ & $10^{12}$ \\
Citrics & $40-140^{10}$ & $20^{10}$ & $16-25^{11}$ & $0.7-1.4^{11}$ \\
Pineapple & $120-180^{9}$ & $30-60^{9}$ & $16-25^{11}$ & $0.7-1.4^{11}$ \\
Tomato & $40^{9}$ & $20^{9}$ & $25^{12}$ & $20^{12}$ \\
\hline \hline
\end{tabular}

1- Agrobyte (2003). 2 - EMBRAPA (2003). 3 - Abreu et al. (2003). 4 - CPAA (2003). 5 - Ferreira (2003). 6 - Silva et al. (2000). 7 - CFSEMG (1989). 8. Malavolta and Dantas (1980). 9 - SEAGRI (2003). 10 - DGPC (2003). 11- Vollenweider (1968). 12 Average limit for sandy soils after Howarth et al. (1996). 13 - Average limit for clay soils after Howarth et al. (1996). 
respectively. For poultry, $\mathrm{N}$ and $\mathrm{P}$ contents are about $1.2 \%$ and $1.3 \%$. Once deposited in soils, rates of nutrient retention and uptake by plants will determine the fraction eventually released to waters, which are similar to those described for $\mathrm{N}$ and $\mathrm{P}$ retention of the natural inputs (NRC, 1993; Bouwman et al. 1997; Bouwman \& Booij, 1998; NRC, 2000). Although some livestock are reared in closed premises the large majority of the region's husbandry is extensive and dominated by bovine. Therefore, we considered that nutrients emitted from this practice will always pass through soils prior to reaching rivers.

Emissions of $\mathrm{N}$ and $\mathrm{P}$ to the studied estuaries from the region's husbandry are independent of basin area and ranged from 19 and 20 t.yr $^{-1}$, for the Ceará Mirim basin, to 701 and 526 t.yr $^{-1}$, for the Mundaú basin, for $\mathrm{N}$ and $\mathrm{P}$ respectively, being dominated by bovine cattle due to its larger number and amount of manure produced per capita. Nitrogen load is relatively smaller than the P load mostly due to ammonium loss to the atmosphere. It is important to note that manure is frequently used as fertilizers, which eventually may result in some export of nutrients in farm products out of the basins. This loss, however, is probably very small since this practice is typical of subsistence, familiar agriculture and is not estimated here.

\section{Wastewaters}

Wastewaters are one of the major sources of nutrients to coastal areas, particularly in urbanized estuaries. When no treatment plants exist, nutrient load from this source is directly proportional to population and the amount of water used per inhabitant (Smith et al., 1997), since $N$ and $P$ concentrations in wastewater vary within a narrow range (I.C. Consultants, 2001). Therefore emission factors can be easily derived from population parameters to estimate inputs from wastewater released to estuaries (Smith et al., 1997; Howarth, 1998; Bidone, 2000; Bidone \& Lacerda, 2002; Martinelli et al., 2002). The estimates presented here

Table 4 - Estimated emissions (t.yr-1) from agriculture and husbandry to the studied estuaries along the Northeastern coast of Brazil.

\begin{tabular}{lcccccc}
\hline \multicolumn{1}{c}{ Basin } & \multicolumn{2}{c}{ Agriculture $^{1}$} & \multicolumn{2}{c}{ Husbandry $^{2}$} & \multicolumn{2}{c}{ Total } \\
\hline Timonha (CE) & $\mathbf{N}$ & $\mathbf{P}$ & $\mathbf{N}$ & $\mathbf{P}$ & $\mathbf{N}$ & $\mathbf{P}$ \\
Acaraú (CE) & 191 & 39 & 81 & 49 & 272 & 88 \\
Coreaú (CE) & 471 & 611 & 595 & 368 & 1066 & 979 \\
Aracatiaçú (CE) & 133 & 101 & 530 & 324 & 663 & 425 \\
Aracatimirim (CE) & 71 & 72 & 146 & 92 & 217 & 164 \\
Curu (CE) & 159 & 161 & 97 & 60 & 256 & 221 \\
Mundaú (CE) & 520 & 115 & 215 & 159 & 735 & 274 \\
Pirangi (CE) & 411 & 373 & 701 & 526 & 1112 & 899 \\
Jaguaribe (CE) & 159 & 251 & 320 & 257 & 479 & 508 \\
Icapui (CE) & 146 & 168 & 145 & 90 & 291 & 258 \\
Apodi (RN) & 88 & 131 & 55 & 32 & 143 & 163 \\
Açu (RN) & 224 & 543 & 314 & 389 & 538 & 932 \\
Guamaré (RN) & 45 & 111 & 88 & 90 & 133 & 201 \\
Ceará Mirim (RN) & 30 & 70 & 170 & 176 & 200 & 246 \\
Guaraíras (RN) & 38 & 24 & 19 & 20 & 57 & 44 \\
Curimataú(RN) & 864 & 147 & 426 & 561 & 1290 & 708 \\
\hline \hline
\end{tabular}

1 - Amount of $\mathrm{N}$ and $\mathrm{P}$ applied for each culture (see table 3). Agriculture area and culture type (IBGE, 2003b; IDEMA, 1999a;b). Average loss rates of applied N (30\%) and P (15\%) from Malavolta and Dantas (1980); CFSEMG (1989) and Silva et al. (2000). 2 - Animal stock from IBGE (2003b). Manure volume in kg.animal ${ }^{-1}$.day ${ }^{-1}$ are: 10, 2.5, 1.0 and 0.18 for cows and horses, pigs, sheep and chicken, respectively (Boyd, 1971). Manure $\mathrm{N}$ and $\mathrm{P}$ concentrations in $\%$ of animal excrete are: $\mathrm{N}=0.6,0.5,0.5$ and 1.2 ; and $\mathrm{P}=0.35,0.3,0.5$ and 1.3 for cows and horses, pigs, sheep and chicken, respectively (Boyd, 1971; Esteves, 1998). Soil nutrient retention: $N=65 \%$ and $\mathrm{P}=70 \%$ (NRC, 1993; 2000; Bouwman and Booij, 1998; Bouwman et al., 1997). 
are based on the latest population census available for the year 2003 and on a detailed inventory of water use by the local population published by Döll \& Hauschild (2002). This survey showed water consumption varying from 82 to 125 (average of 85 ) L.inhab ${ }^{-1}$.day ${ }^{-1}$, in rural areas along the coast, to 100 to 150 (average of 115) L.inhab $^{-1}$. day ${ }^{-1}$ in urban areas among the 16 studied basins' population. Nutrient concentrations in wastewater were those suggested by von Sperling (1996) based on Brazilian conditions. Finally, the assumption of no-treatment prior to release was used, since the availability of sewage treatment in non-metropolitan areas of the northeastern region of Brazil reaches only $10 \%$ of its population.

The estimates presented in table 5 shows $\mathrm{N}$ inputs varying from 17 to 400.5 t.yr $^{-1}$ and $P$ inputs varying from 4.5 to $112.5 \mathrm{t}^{\mathrm{yr}} \mathrm{r}^{-1}$, with maximum values at the Apodi basin and minimum in the low populated Guamaré basin. Comparisons of the emission factors calculated for this study (4 - 8 g.inhab ${ }^{-1}$.day ${ }^{-1}$ and 0.6 - 2.9 g.inhab $^{-1}$.day ${ }^{-1}$, for $\mathrm{N}$ and $\mathrm{P}$ respectively) with others from the literature show our values in the lower range of reported factors, since emissions are much lower than those reported for urbanized metropolitan areas. (Howarth, 1998; Bidone, 2000; Bidone \& Lacerda, 2002; Martinelli et al., 2002).

\section{Urban runoff and solid waste disposal}

Major parameters controlling nutrient loss by runoff from urban areas are the area of impermeable surfaces, the number and dimensions of habitations and annual rainfall. For solid wastes disposal, the main parameters controlling contaminant emissions are population size and per capita production of solid wastes and their disposal method (Davis et al., 2001), as well as the average concentrations of $\mathrm{N}$ and $\mathrm{P}$ in runoff waters from landfill sites and the local rainfall levels (NRC, 2000). In the studied basins, large urbanized areas are absent. Also, most villages and cities present low levels of soil impermeability. Solid waste disposal is mostly restricted to solids present in wastewaters, already mentioned. Therefore, $\mathrm{N}$ and $\mathrm{P}$ emissions from this source are relatively small, ranging from $0.1 \mathrm{~kg} . \mathrm{yr}^{-1}$ (for both

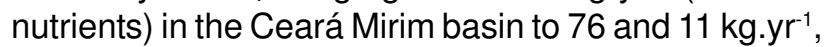
in the Guamaré basin, for $\mathrm{N}$ and $\mathrm{P}$ respectively (Table 5), representing less than $10 \%$ of the emissions from wastewaters.

\section{Aquaculture}

Shrimp farms are large exporters of nutrients to the coastal environments (Burford et al., 2003). The activity uses large amounts of fertilizers and feed to maintain one of the highest productivity rates reported (about 6.2 t.ha.yr $^{-1}$ ) (ABCC, 2003). Typical fertilizers application reaches 40 and $10 \mathrm{~kg}^{-h^{-1}}$. production cycle${ }^{1}$ (100 and $\left.25 \mathrm{~kg} \cdot \mathrm{ha}^{-1} \cdot \mathrm{yr}^{-1}\right)$ of urea and superphosphate, respectively, assuming food conversion rates of 1.5 to 1.8 (Nunes, 2001). Notwithstanding the economic importance of intensive shrimp farming in a global scale, there are only a few studies estimating the emission factors of nutrients from this activity. However, since there is a tendency to uniform shrimp farming technology worldwide, it is reasonable to use emission factors estimated for any area in the world.

At the Jaguaribe River Estuary, for example, Abreu et al. (2003) reported total excess $P$ concentrations in outgoing waters during a monitoring year period in a typical farm varying from 0.06 to 0.18 $\mathrm{mg} \cdot \mathrm{L}^{-1}$. Considering the water renewal time of the farm, which generally varies from $5 \%$ to $10 \%$ per day, the estimated average emission factor for $P$ was 0.05 kg.ha${ }^{1}$.day ${ }^{-1}$ (about $12 \mathrm{~kg} \cdot \mathrm{ha}^{-1} \cdot \mathrm{yr}^{-1}$ ), considering 2.3 production cycles per year, the typical number of production cycles of shrimp farms of NE Brazil. Measured excess $\mathrm{N}$ concentrations in effluent waters (including $\mathrm{NO}_{3}, \mathrm{NO}_{2}^{-}$ and $\mathrm{NH}_{3}+\mathrm{NH}_{4}{ }^{+}$only) varied from 0.16 to $0.39 \mathrm{mg} \cdot \mathrm{L}^{-1}$, resulting in total $\mathrm{N}$ concentrations, when corrected to include particulate organic N, since up to $70 \%$ of the $\mathrm{N}$ present in the effluent is organic particulate $\mathrm{N}$ (Burford et al., 2003), of 0.52 to $1.29 \mathrm{mg.L} \mathrm{L}^{-1}$. this resulted in an average emission factor for $\mathrm{N}$ of about $0.47 \mathrm{~kg} \cdot$ ha $^{-1}$.day ${ }^{1}$, about $110 \mathrm{~kg} \cdot \mathrm{ha}^{-1} \cdot \mathrm{yr}^{-1}$. In another farm in the same river Figueiredo et al. (2005) estimated annual P input of $9.2 \mathrm{~kg} \cdot \mathrm{ha}^{-1} \cdot \mathrm{yr}^{-1}$.

Experimental data from Australian farms reported total $\mathrm{N}$ and $\mathrm{P}$ concentrations in effluent waters of 0.98 mg. $\mathrm{L}^{-1}$ and $0.13 \mathrm{mg} . \mathrm{L}^{-1}$ respectively (Burford et al., 2003), resulting in emission factors of $0.99-1.18 \mathrm{~kg}^{-\mathrm{ha}^{-1}}$.day ${ }^{1}$ and $0.06 \mathrm{~kg} \mathrm{ha}^{-1}$. day ${ }^{-1}$, and annual emissions of 290 and $16 \mathrm{~kg}$ ha $^{-1}$, for $\mathrm{N}$ and $\mathrm{P}$ respectively (Jackson et al., 2003; Burford et al., 2003). In the Gulf of California, Mexico, Paez-Osuna et al. (1999; 2003) estimated N and $\mathrm{P}$ export from the local shrimp farms of about 112 and $32 \mathrm{~kg} \cdot \mathrm{ha}^{-1} \cdot \mathrm{yr}^{-1}$, respectively. A comparison of existing $\mathrm{N}$ and $\mathrm{P}$ emission factors for intensive shrimp farming worldwide is presented in table 6 . This comparison suggests a good consistency of the estimated emission factors of $\mathrm{N}$ and, in particular for $\mathrm{P}$, for shrimp farms in different parts of the world, an expected result due to the similarity of the technology used.

Estimates of the total $\mathrm{N}$ and $\mathrm{P}$ contribution from shrimp farming to the different basins studied, based on the range of emission factors displayed in table 6 are presented in table 7 . Nitrogen and $P$ emissions vary from the smaller contribution to the Ceará Mirim basin (9 tN.yr ${ }^{-1}$ and $0.7 \mathrm{tP}_{\mathrm{yr}} \mathrm{r}^{-1}$ ), with only 30 ha of ponds, to 485 tN.yr ${ }^{-1}$ and 35 tP.yr $^{-1}$ at the larger Açu basin, with 1,679 ha of pond area. Considerable emissions from shrimp farms also occur in the Jaguaribe, Mundaú and Apodi basins. 
Table 5 - Estimated emissions from wastewaters and urban runoff. including leaching of solid wastes disposal sites for the sixteen basins studied $\left(\right.$ t.yr $\left.{ }^{-1}\right)$.

\begin{tabular}{lcccccc}
\hline \multicolumn{1}{c}{ Basin } & \multicolumn{2}{c}{ Waste } & waters & \multicolumn{2}{c}{ Urban runoff $^{2}$} & \multicolumn{2}{c}{ Total $^{3}$} \\
\hline Timonha (CE) & $\mathrm{N}$ & $\mathrm{P}$ & $\mathrm{N}$ & $\mathrm{P}$ & $\mathrm{N}$ & $\mathrm{P}$ \\
Acaraú (CE) & 50.1 & 14.0 & 3.1 & 0.1 & 53 & 14 \\
Coreaú (CE) & 238.9 & 66.9 & 15.5 & 0.5 & 254 & 67 \\
Aracatiaçú (CE) & 233.0 & 65.2 & 14.7 & 0.5 & 248 & 66 \\
Aracatimirim (CE) & 56.6 & 15.9 & 3.6 & 0.1 & 60 & 16 \\
Curu (CE) & 52.5 & 14.7 & 3.6 & 0.1 & 56 & 15 \\
Mundaú (CE) & 98.3 & 27.5 & 6.5 & 0.2 & 105 & 28 \\
Pirangi (CE) & 250 & 70 & 17 & 0.6 & 267 & 71 \\
Jaguaribe (CE) & 76.5 & 21.4 & 4.9 & 0.2 & 81 & 22 \\
Icapui (CE) & 152.0 & 42.6 & 9.4 & 0.3 & 161 & 43 \\
Apodi (RN) & 27.5 & 7.7 & 1.9 & 0.1 & 29 & 8 \\
Açu (RN) & 400.5 & 112.5 & 48 & 7 & 449 & 120 \\
Guamaré (RN) & 96 & 27 & 7 & 1 & 103 & 28 \\
Ceará Mirim (RN) & 17 & 4.5 & 76 & 11 & 93 & 16 \\
Guaraíras (RN) & 96.5 & 27 & $<1$ & $<1$ & 33 & 10 \\
Curimataú (RN) & 57 & 16 & 7 & 2 & 107 & 29 \\
\hline \hline
\end{tabular}

1. Nutrient concentrations in waste waters: $\mathrm{N}=35-70 \mathrm{mg} \cdot \mathrm{L}^{-1} ; \mathrm{P}=5-25 \mathrm{mg} \cdot \mathrm{L}^{-1}$ (von Sperling. 1996). Population data from IBGE

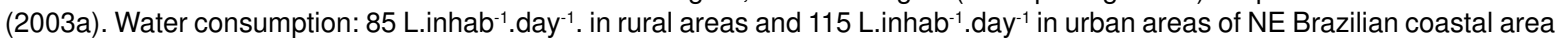
(Döll and Hauschild. 2002). 2 - Population parameters from IBGE (2003a). Annual rainfall from Hydroservice (1998). Includes leaching of solid wastes disposal sites. Solid waste production per inhabitant from ABES (1983). Average constructed housing unit of $50 \mathrm{~m}^{2}$. Average N and P concentrations in runoff from NRC (2000) and Binner et al. (1996). 3 - Totals are rounded to unit.

Table 6 - Comparison of average emission factors $\left(\mathrm{kg} \cdot \mathrm{ha}^{-1}\right.$.day $\left.{ }^{-1}\right)$ of $\mathrm{N}$ and $\mathrm{P}$ from shrimp farms based on instantaneous data on nutrient concentrations in effluent waters.

\begin{tabular}{lcc}
\hline \multicolumn{1}{c}{ Location } & $\mathrm{N}$ & $\mathrm{P}$ \\
\hline Ceará State. Brazil $^{1,2}$ & $0.47^{3}$ & $0.05^{4}$ \\
Australia $^{5}$ & $1.08^{6}$ & 0.06 \\
Gulf of California. Mexico $^{7}$ & 0.58 & 0.12 \\
Upper Jaguaribe Basin, Brazil $^{8}$ & - & 0.03 \\
Range of emission factors & $0.27-1.08$ & $0.03-0.12$ \\
\hline \hline
\end{tabular}

1 - This study and Abreu et al. (2003). 2 - Water renewal rate $5 \%$ to $10 \%$.dia ${ }^{-1}$. Pond depth of $1.0 \mathrm{~m}$, volume exchanged of $5 \times 10^{5}$ L.ha $^{-1}$.day ${ }^{-1}$ (Nunes. 2001; Abreu et al., 2003). $3-\mathrm{N}$ estimates based on approximate speciation given in Burford et al. (2003), i.e. $70 \%$ of the total $\mathrm{N}$ being particulate organic $\mathrm{N}$ and actual concentrations of $\mathrm{NO}_{3}, \mathrm{NO}_{2}$ and $\mathrm{NH}_{4}$ (Abreu et al., 2003). 4 - Based on actual nutrient concentrations in effluent waters monitored during one year (Abreu et al., 2003). 5 - Jackson et al. (2003). 6 - Denitrification rate of about 5\% (Burford et al., 2003). 7 - Paez-Osuna et al. (1999; 2003). 8 Estimated from original data in Figueiredo et al. (2005). 
Table 8 compares the emission yields, standardized to $\mathrm{kg}^{\mathrm{km}} \mathrm{km}^{-2} \cdot \mathrm{yr}^{-1}$, of the different natural and anthropogenic sources of $\mathrm{N}$ and $\mathrm{P}$ obtained under the specific conditions of the 16 basins studied. Average yields for urban runoff and solid waste disposal and waste waters are in general lower than those from other sources. Natural sources of $\mathrm{N}$ and $\mathrm{P}$ are still a significant contribution to the nutrient loads in these estuaries. An expected result since most basins lack significant urbanized areas. Intensive shrimp farming presents the largest average yield for $\mathrm{N}\left(201 \mathrm{~kg} \cdot \mathrm{km}^{-2} \cdot \mathrm{yr}^{-1}\right)$, followed by agriculture (191 kg.km-2.yr-1) and husbandry (164

Table 7 - Estimates for $\mathrm{N}$ and $\mathrm{P}$ emissions from shrimp farms ${ }^{1}$ to the studied estuaries in NE Brazil (t.yr-1).

\begin{tabular}{lccc}
\hline \hline Basin & $\begin{array}{c}\text { Pond } \text { area }^{2} \\
\text { (ha) }\end{array}$ & N emission $^{3.4}$ & P emission $^{4}$ \\
\hline Timonha (CE) & 147 & 44 & 3.1 \\
Acaraú (CE) & 743 & 222 & 16 \\
Coreaú (CE) & 439 & 131 & 9.3 \\
Aracatiaçú (CE) & 62 & 19 & 1.3 \\
Aracatimirim (CE) & 58 & 18 & 1.2 \\
Curu (CE) & 110 & 33 & 2.3 \\
Mundaú (CE) & 42 & 13 & 0.9 \\
Pirangi (CE) & 90 & 28 & 1.9 \\
Jaguaribe (CE) & 1,259 & 375 & 27 \\
Icapui (CE) & 59 & 18 & 1.3 \\
Apodi (RN) & 874 & 253 & 18 \\
Açu (RN) & 1,679 & 485 & 35 \\
Guamaré (RN) & 414 & 120 & 8.7 \\
Ceará Mirim (RN) & 30 & 9 & 0.7 \\
Guaraíras (RN) & 747 & 216 & 16 \\
Curimataú (RN) & 1,070 & 293 & 23 \\
\hline \hline
\end{tabular}

1 - From emission factors presented in table 5 and average production cycle per year of 2.3 and 30 initial days without water exchange and further exchange volume of $5 \%$ per day, from ABCC (2003) and Nunes et al. (2003). 2 - From ABCC (2003). 3 - Assuming $70 \%$ of the total $N$ in the effluent discharge being particulate organic N (Burford et al., 2003). 4 - From emission factors presented in table 6.

Table 8 - Range and average (in parenthesis) of emission factors from the different anthropogenic sources of Nitrogen and Phosphorus, standardized to $\mathrm{kg}_{\mathrm{km}} \mathrm{km}^{-2} \mathrm{yr}$, for the specific conditions existing in the estuarine basins studied along the coast northeastern Brazil.

\begin{tabular}{lcc}
\hline \hline Source & $\mathrm{N}$ & $\mathrm{P}$ \\
\hline Natural sources & $59-133(79)$ & $12-61(45)$ \\
Waste water & $31-410(85)$ & $9-115(24)$ \\
Husbandry & $84-1,311(164)$ & $52-1,726(111)$ \\
Agriculture & $28-2,658(191)$ & $22-557(151)$ \\
Urban runoff & $2-138(5)$ & $0.1-20(0.3)$ \\
Aquaculture & $6-664(201)$ & $0.4-77(15)$ \\
\hline \hline
\end{tabular}


$\left.\mathrm{kg} \cdot \mathrm{km}^{-2} \cdot \mathrm{yr}^{-1}\right)$. For $\mathrm{P}$, largest average yields are from agriculture $\left(151 \mathrm{~kg} \cdot \mathrm{km}^{-2} . \mathrm{yr}^{-1}\right)$ and husbandry $(111 \mathrm{~kg} . \mathrm{km}$ $\left.{ }^{2} . \mathrm{yr}^{-1}\right)$. Although shrimp farming also presents a relatively high yield $\left(15 \mathrm{~kg} \cdot \mathrm{km}^{-2} \cdot \mathrm{yr}^{-1}\right)$, all other natural and anthropogenic sources with the exception of urban runoff presents higher $\mathrm{P}$ yields.
The total loads of $\mathrm{N}$ and $\mathrm{P}$ for each studied basin from anthropogenic sources are presented in table 9. Notwithstanding the high emission factors and yields from shrimp farming, the larger loads of nutrients are due to agriculture and husbandry, which occupy much larger areas. Urban runoff is a negligible source of $\mathrm{N}$

Table 9 - Average estimates of $\mathrm{N}$ and $\mathrm{P}$ emissions (t.yr $\left.{ }^{-1}\right)$ from anthropogenic sources in the studied basin along the NE Brazil. The relative contribution (\%) of each individual source appears in parenthesis.

\begin{tabular}{|c|c|c|c|c|c|c|}
\hline \multirow[t]{2}{*}{ Basin } & \multicolumn{6}{|c|}{ Source } \\
\hline & Wastewaters & Husbandry & Agriculture & Urban runoff & Aquaculture & Total \\
\hline \multicolumn{7}{|l|}{ Timonha (CE) } \\
\hline $\mathrm{N}$ & $50(14)$ & $81(22)$ & $191(53)$ & $3(1)$ & 37 (10) & 362 \\
\hline $\mathrm{P}$ & $14(13)$ & $49(47)$ & $39(37)$ & $<1(<1)$ & $3(3)$ & 105 \\
\hline \multicolumn{7}{|l|}{ Acaraú (CE) } \\
\hline $\mathrm{N}$ & $239(16)$ & $595(39)$ & $471(31)$ & $16(1)$ & $188(12)$ & 1509 \\
\hline $\mathrm{P}$ & $67(6)$ & $368(35)$ & $611(58)$ & $1(<1)$ & $16(2)$ & 1063 \\
\hline \multicolumn{7}{|l|}{ Coreaú (CE) } \\
\hline $\mathrm{N}$ & $233(23)$ & $530(52)$ & $133(13)$ & $15(1)$ & $111(11)$ & 1022 \\
\hline $\mathrm{P}$ & $65(13)$ & $324(65)$ & $101(20)$ & $1(<1)$ & $9(2)$ & 500 \\
\hline \multicolumn{7}{|c|}{ Aracatiaçú (CE) } \\
\hline $\mathrm{N}$ & 57 (19) & $146(50)$ & $71(24)$ & $4(1)$ & $16(5)$ & 294 \\
\hline$P$ & $16(9)$ & $92(51)$ & $72(40)$ & $<1(<1)$ & $1(1)$ & 181 \\
\hline \multicolumn{7}{|c|}{ Aracatimirim (CE) } \\
\hline $\mathrm{N}$ & $53(16)$ & $97(30)$ & $159(49)$ & $4(1)$ & $15(5)$ & 328 \\
\hline $\mathrm{P}$ & $15(6)$ & $60(25)$ & $161(68)$ & $<1(<1)$ & $1(1)$ & 237 \\
\hline \multicolumn{7}{|l|}{ Curu (CE) } \\
\hline $\mathrm{N}$ & $98(11)$ & $215(25)$ & $520(60)$ & 7 (1) & $28(3)$ & 868 \\
\hline$P$ & $28(9)$ & $159(52)$ & $115(38)$ & $<1(<1)$ & $2(1)^{\prime}$ & 305 \\
\hline \multicolumn{7}{|l|}{ Mundaú (CE) } \\
\hline $\mathrm{N}$ & $250(18)$ & $701(50)$ & $411(30)$ & $17(1)$ & $11(1)$ & 1390 \\
\hline $\mathrm{P}$ & $70(7)$ & $526(54)$ & $373(38)$ & $1(<1)$ & $1(0)$ & 971 \\
\hline \multicolumn{7}{|l|}{ Pirangi (CE) } \\
\hline $\mathrm{N}$ & 77 (13) & $320(55)$ & $159(27)$ & $5(1)$ & $24(4)$ & 585 \\
\hline $\mathrm{P}$ & $21(5)$ & $257(58)$ & $161(36)$ & $<1(<1)$ & $2(0)$ & 441 \\
\hline \multicolumn{7}{|c|}{ Jaguaribe (CE) } \\
\hline $\mathrm{N}$ & $152(20)$ & 145 (19) & $146(19)$ & $9(1)$ & $318(41)$ & 770 \\
\hline $\mathrm{P}$ & $43(13)$ & $90(27)$ & $168(51)$ & $<1(<1)$ & $27(8)$ & 328 \\
\hline \multicolumn{7}{|l|}{ Icapui (CE) } \\
\hline $\mathrm{N}$ & $28(15)$ & $55(29)$ & $88(47)$ & 2 (1) & $15(8)$ & 188 \\
\hline$P$ & $8(5)$ & 32 (19) & $131(76)$ & $<1(<1)$ & $1(1)$ & 172 \\
\hline \multicolumn{7}{|l|}{ Apodi (RN) } \\
\hline $\mathrm{N}$ & $400(33)$ & $314(26)$ & $224(19)$ & $48(4)$ & 214 (18) & 1200 \\
\hline$P$ & $112(12)$ & $289(30)$ & $543(56)$ & $7(1)$ & $18(2)$ & 969 \\
\hline \multicolumn{7}{|l|}{ Açu (RN) } \\
\hline $\mathrm{N}$ & 97 (15) & $88(14)$ & $45(7)$ & $7(1)$ & $411(63)$ & 648 \\
\hline $\mathrm{P}$ & 27 (10) & $90(34)$ & $111(42)$ & $1(<1)$ & $35(13)$ & 264 \\
\hline \multicolumn{7}{|c|}{ Guamaré (RN) } \\
\hline $\mathrm{N}$ & $17(4)$ & $170(43)$ & $30(8)$ & 76 (19) & $102(26)$ & 395 \\
\hline $\mathrm{P}$ & $5(2)$ & $176(65)$ & $70(26)$ & $11(4)$ & $9(3)$ & 271 \\
\hline \multicolumn{7}{|c|}{ Ceará-Mirim (RN) } \\
\hline $\mathrm{N}$ & $32(33)$ & $19(20)$ & $38(39)$ & $1(1)$ & $7(8)$ & 97 \\
\hline $\mathrm{P}$ & $9(16)$ & $20(37)$ & $24(44)$ & $1(2)$ & $1(1)$ & 55 \\
\hline \multicolumn{7}{|c|}{ Guaraíras (RN) } \\
\hline$N$ & $97(6)$ & $426(27)$ & $864(55)$ & $10(1)$ & $183(12)$ & 1580 \\
\hline $\mathrm{P}$ & $27(4)$ & $561(75)$ & $147(20)$ & $2(<1)$ & $16(2)$ & 753 \\
\hline \multicolumn{7}{|c|}{ Curimataú (RN) } \\
\hline $\mathrm{N}$ & $57(5)$ & $190(15)$ & $749(60)$ & $7(1)$ & $248(20)$ & 1251 \\
\hline $\mathrm{P}$ & $17(5)$ & $244(69)$ & $67(19)$ & $1(<1)$ & $23(7)$ & 352 \\
\hline
\end{tabular}


and $P$ in all basins, representing less than $2 \%$ of the total emission, with the exception of the Guamaré basin where $19 \%$ of the $\mathrm{N}$ emission come from this source. Wastewaters contribute with significant loads of $\mathrm{N}$ and $\mathrm{P}$ to the more populated basin (Apodi) which harbors over 240.000 inhabitants $(33 \%$ and $12 \%$, for $\mathrm{N}$ and $\mathrm{P}$ respectively). Intensive shrimp farming is, however, the major contributor of $\mathrm{N}$ in the Jaguaribe $(41 \%)$ and $\mathrm{Açu}$ $(63 \%)$ basins. Also at the Guamaré basin it contributes with $26 \%$ of the total $N$ load. Contribution of $P$ from intensive shrimp farming is relatively small varying from $<5 \%$ in most basins to a maximum contribution of $13 \%$ at the Açu basin.

Although the relative contribution of intensive shrimp farming is small in most of the studied area, except at the Jaguaribe and Açu basins, the location of farms adjacent to estuaries makes possible direct inputs to waters, while most other emissions go firstly to soils before eventually being transported to surface waters.

\section{CONCLUSIONS}

The results presented here show that even in areas of low human occupation such as the NE semiarid coast of Brazil, anthropogenic emissions of $\mathrm{N}$ and $P$ are significant sources of these nutrients to estuaries. Although all studied basins present low population densities, inputs from agriculture, husbandry and shrimp farming are considerable and can alter the water quality of the receiving estuaries. Intensive shrimp farming presents the largest yields for $\mathrm{N}$ among the studied basins. However, only in two estuary (Jaguaribe and $\mathrm{Açu}$ ), where pond area reaches 1,260 ha and 1,680 ha respectively, it is the most important source of N. Shrimp farm contribution to the total $\mathrm{P}$ emission is relatively small in all estuaries. However, since emissions from this source are directly disposed to estuarine waters the response of coastal ecosystem metabolism to shrimp farm effluents may be more rapid than from other sources and control of these emissions are critical to control the eventual onset of eutrophication.

\section{ACKNOWLEDGEMENTS}

This study was supported by the project "Instituto do Milênio" from the National Research Council of Brazil (CNPq), Fundação de Amparo a Pesquisa do Estado do Rio de Janeiro (FAPERJ) through its PRONEX/ FAPERJ Program Project no. E26-171.175/2003 and FINEP/RECARCINE Initiative. I am particularly thankful to many students who greatly helped gathering information on the studied sites.

\section{REFERENCES}

ABCC (Associação Brasileira dos Criadores de Camarão). 2003. Censo da Produção do Camarão Marinho Cultivado. ABCC, Recife, 7p.

ABES (Associação Brasileira de Engenharia Sanitária e Ambiental). 1983. Catálogo Brasileiro de Engenharia Sanitária. ABES, Rio de Janeiro, 127p.

Abreu, I.M.; Lacerda, L.D. \& Marins, R.V. 2003. Estimativa de emissões de Carbono, Fósforo e Nitrogênio para o Estuário do Rio Jaguaribe (CE). In: Caludino-Salle, V; Toinini, I.M \& Dantas, E.W.C. (ed.). Anais do IX Congresso de Ecologia do Brasil, Fortaleza. 163-164 pp.

Agrobyte. 2003. Cana de Açúcar. www.agrobyte.com.br/ cana.htm (accessed in 01/2007).

Barcellos, C. \& Lacerda, L.D. 1994. Cadmium and Zinc source assessment in Sepetiba Bay and basin region. Environ. Monitor. Assess. 29: 183-189.

Bidone, E.D. 2000. Análise econômica-ambiental aplicada à contaminação de águas fluviais de pequenas bacias costeiras do Estado do Rio de Janeiro. In: Esteves, F.A. \& Lacerda, L.D. (ed.); Ecologia de Restingas e Lagoas Costeiras, Ed. UFRJ, Rio de Janeiro. 371-394 pp.

Bidone, E.D. \& Lacerda, L.D. 2002. A preliminary approach of the link between socio-economic and natural indicators into a driver-pressure-impactresponse framework case study: Guanabara Bay basin, Rio de Janeiro, Brazil. In: Lacerda, L.D.; Kremer, H.H.; Kjerfve, B.; Salomons, W.; MarshallCrossland, J.I. \& Crossland, J.C. (ed.) South American Basins: LOICZ Global Change Assessment and Synthesis of River Catchment Coastal Sea Interaction and Human Dimensions. LOICZ Reports \& Studies No. 21. Texel. 142-153 $\mathrm{pp}$.

Binner, E.; Lechner, P.; Ziegler, C. \& Riehl-Herwirsch, G. 1996. Breitenau landfill - Water balance, emissions and a look into the landfill body. Breitenau Landfill, Viena, 27p.

Bouwman, A.F. \& Booij, H. 1998. Global use and trade of feedstuff and consequences for the nitrogen cycle. Nutr. Cycl. Agroecosyst. 52: 262-267.

Bouwman, A.F.; Lee, D.S.; Asman, A.H.; Dentener, F.J.; van der Hoek, K.W.A. \& Olivier, J.G.J. 1997. A global high-resolution inventory for ammonia. Global Biogeochem. Cycl. 11: 561-587.

Boyd, C.E., 1971. The limnological role of aquatic macrophytes and their relationship to reservoir management. American Fisheries Society Special Publication 8. Washington. 153-166 pp.

Boynton, W.R.; Garber, J.H.; Summers, R. \& Kemp, W.M. 1995. Inputs, transformation, and transport of 
nitrogen and phosphorus in Cheasapeake Bay and selected tributaries. Estuaries. 19: 285-314.

Bricker, S.B.; Clement, C.G.; Pirhalla, D.E.; Orlansdo, S.P. \& Farrow, D.R.G. 1999. National Estuarine Eutrophication Assessment: Effects of Nutrient Enrichment in the Nation's Estuaries. NOAA, National Ocean Service, Special Projects Office and the National Centers for coastal Ocean Science. Silver Springs, MD, 71p.

Bricker, S.B.; Ferreira, J.G. \& Simas, T. 2003. An integrated methodology for assessment of estuarine trophic status. Ecol. Model. 169: 39-60.

Brunner, U. 1998. The Biogeochemical cycles of phosphorus: a review of local and global consequences of the atmospheric input. Technol. Environ. Chem. 167: 171-188.

Burford, M.A.; Costanzo, S.D.; Dennison, W.C.; Jackson, C.J.; Jones, A.B.; McKinnon, A.D.; Preston, N.P. \& Trott, L.A. 2003. A synthesis of dominant ecological processes in intensive shrimp ponds and adjacent coastal environments in NE Australia. Mar. Pollut. Bull. 46: 1456-1469.

Burns, D.A. 2004. The effects of atmospheric nitrogen deposition in the rocky mountais of Colorado and Southern Wyoming, USA-A critical review. Environ. Pollut. 127: 257-269.

CFSEMG (Comissão de Fertilidade do Estado de Minas Gerais). 1989. Recomendações para o Uso de Corretivos e Fertilizantes em Minas Gerais. Escola Superior de Agricultura de Lavras, Lavras, 13p.

CPAA (Centro de Pesquisas do Açúcar e do Álcool). 2003. Insumos de Adubação Aplicados ao Sistema Agroflorestal. Empresa Brasileira de Pesquisa Agropecuária. www.cpaa.embrapa.br/portfolio/ produtos.htm (accessed in 01/2007).

Davis, A.P.; Shokouhian, M. \& Shubei, M. 2001. Loading estimates of lead, copper, cadmium and zinc in urban runoff from specific sources. Chemosphere. 44: 9971009.

DGPC (Divisão Geral de Proteção das Culturas). 2003. Produção Integrada de Citrinos, Ministerio da Agricultura, Desenvolvimento Rural e das Pescas. (DGPC), Oeiros. www.dgpc.min-agricultura.pt (accessed in 01/2007).

Doll, P. \& Hauschild, M. 2002. Model-based scenarios of water use in two semi-arid Brazilian states. Reg. Environ. Change. 2:150-162.

EEA (European Environmental Agency). 1999. Nutrients in European Ecosystems. Environmental Assessment Report No. 4, Office for Official Publications of the European Communities, (EEA), Luxemburg, 156p.

EMBRAPA (Empresa Brasileira de Pesquisa Agropecuária). 2003. Agroecologia da Cana de Açú- car. http://www.cana.cnpm.embrapa.br/ agroeco.html (accessed in 01/2007).

EPA (Environmental Protection Agency). 2002. National Recommended Water Quality Criteria. Office of Water, (EPA), EPA-822-R-02-047, Washington, 36p.

Esteves, F.A. 1998. Fundamentos de Limnologia. 2은 ed., Editora Interciência, Rio de Janeiro, 606p.

Ferreira, J.M.S. 2003. Produção Integrada de Coco. EMBRAPA Tabuleiros Costeiros, Aracaju, 107p.

Figueiredo, M.C.B.; Araújo, L.F.P.; Gomes, R.B.; Rosa, M.F.; Paulino, W.D. \& Morais, L.F.S. 2005. Impactos ambientais do lançamento de efluentes da carcinicultura em águas interiores. Engen. Sanit. Ambient. 10: 167-174.

Golley F.B.; Mc Guiness J.T.; Clements R.G.; Child G.I. \& Duever M.J. 1978. Ciclagem de minerais em um ecossistema de floresta tropical úmida. EDUSP, São Paulo, 257p.

Gouldie, A. 1987. The Human Impact on the Natural Environment. $2^{\circ}$ ed., Cambridge University Press, Massachusetts, 338p.

Greenland, D.J. \& Lal, R. 1977. Soil Conservation and Management in the Humid Tropics. Willey, Chischester, 256p.

Guedes, J.E. 2003. Diagnóstico geoquímico-ambiental do Rio Jundiaí nas imediações da cidade de Macaíba/RN. MSc Dissertation, Centro de Ciências Exatas e da Terra, Universidade Federal do Rio Grande do Norte, Natal, 181p.

Hidroservice. 1998. Plano Estadual de Recursos Hídricos. Relatório Síntese. Secretaria estadual de Recursos Hídricos, HE1358-R30/1198, Natal, 235p.

Howarth, R.W.; Jensen, H.S.; Marino, R. \& Postma, H. 1995. Transport to and processing of phosphorus in near-shore and oceanic waters. In: Tissen, $\mathrm{H}$. (ed.), Phosphorus in the Global Environment. John Wiley \& Sons Ltd., pp. 323-345.

Howarth, R.W.; Billen, D.; Swaney, A.; Townsend, N.; Janarski, K.; Lajtha, K.; Downing, J.A.; Elmgren, R.; Caraco, N.; Jordan, T.; Berendse, F.; Freney, J.; Kudeyorov, V.; Murdcoh, P. \& Zhao-Liang, Z. 1996. Regional nitrogen budgets and phosphorus fluxes from the drainages to the North Atlantic Ocean. Biogeochemistry. 46: 203-231.

Howarth, R.W. 1998. An assessment of human influences on inputs of nitrogen to estuaries and continental shelf of the North Atlantic Ocean. Nutr. Cycl. Agroecosyst. 52: 213-223.

I.C. Consultants. 2001. Pollutants in urban waste water and sewage sludge. The Office for Official Publications of the European Communities, Luxembourg.

IBGE (Instituto Brasileiro de Geografia e Estatística). 2003a. Censo demográfico 2003. http:// 
www.ibge.gov.br/cidadesat/default.php (accessed in 01/2007).

IBGE (Instituto Brasileiro de Geografia e Estatística). 2003b. Produção Pecuária Municipal 1999. http:// www.ibge.gov.br/cidadesat/default.php (accessed in 01/2007)

IDEMA (Instituto de Desenvolvimento Econômico e Meio Ambiente do Rio Grande do Norte). 1999a. Informativo Municipal. Canguaretama, vol. 5. Natal. 1-14 pp.

IDEMA (Instituto de Desenvolvimento Econômico e Meio Ambiente do Rio Grande do Norte). 1999b. Informativo Municipal. Pedro Velho, vol. 5. Natal. 14-23 pp, Jackson, C.; Preston, N.P.; Thompson, P. \& Burford, M. 2003. Nitrogen budget and effluent nitrogen components at an intensive shrimp farm. Aquaculture. 218: 397-411.

Johnson, D.W. \& Lindberg, S.E. 1998. Atmospheric Deposition and Forest Nutrient Cycling. Springer Verlag, Berlin, 707p.

Lacerda, L.D.; Guerra, T.; Castilhos, Z.C.; Hatje, V.; Canesin, F.P. \& Cunha, L.C. 1995. Heavy metals atmospheric inputs from energy generation in Brazil. In: CEP Consultants (ed.), Proceedings of the 10th International Conference on Heavy Metals in the Environment, Hamburg. 1:81-83.

Lacerda, L.D. \& Marins, R.V. 1997. Anthropogenic mercury emissions to the atmosphere in Brazil: the impact of gold mining. J. Geochem. Explor. 58:223229.

Lacerda, L.D.; Vaisman, A.G.; Maia L.P.; Cunha, E. \& Silva, C.A.R. 2006. Relative importance of nitrogen and phosphorus emissions from shrimp farming and other anthropogenic sources for six estuaries along the NE Brazilian coast. Aquaculture. 253: 433-446.

Lima, L.C.; Morais, J.O. \& Souza, M.J.N. 2000. Compartimentação Territorial e Gestão Regional do Ceará. Editora FUNECE, Fortaleza, 268p.

Maia, L.P. 2004. Vulnerabilidade e capacidade suporte dos estuários do Estado do Rio Grande do Norte. LABOMAR/IDEMA, Universidade Federal do Ceará, Fortaleza, 35p.

Malavolta, E. \& Dantas, J.P. 1980. Nutrição e adubação do milho. In: Paterniani, E. (ed.). Melhoramento e Produção do Milho no Brasil. $2^{\circ}$ ed., Fundação Cargill, São Paulo. 429-479 pp.

Marins R.V.; Lacerda L.D. \& Villas Boas R.C. 1998. Mercury emissions into Sepetiba Bay basin, SE Brazil. Ciênc. Cult. 50: 293-297.

Marins R.V.; Lacerda L.D. \& Villas Boas R.C. 1999. Relative importance of non-point sources of mercury to an industrialized coastal system, Sepetiba Bay, SE Brazil. In Ebinhaus R.; Turner R.R.; Lacerda L.D.; Vasiliev O. \& Salomons W. (ed.) Mercury Contaminated Sites: Characterization, Risk
Assessment and Remediation. Springer Verlag, Berlin. 207-220 pp.

Martinelli, L.A.; Silva, A.M.; Camargo, P.B.; Moretti, L.R.; Tomazelli, A.C.; Silva, D.M.L.; Fisher, E.G.; Sonoda, K.C. \& Salomão, M.S.M.B. 2002. Levantamento de cargas orgânicas lançadas nos rios do Estado de São Paulo. Biota Neotropica. 2: 1-18.

Mello, W.Z. 2001. Precipitation chemistry in the coast of the Metropolitan Region of Rio de Janeiro, Brazil. Environ. Pollut. 114: 235-242.

Mello, W.Z. 2003. Composição química da chuva no litoral da região metropolitana do Rio de Janeiro. Anais do IX Congresso Brasileiro de Geoquímica, Sociedade Brasileria de Geoquímica, Belém, 6-8 pp.

NRC (National Research Council). 1993. Soil and Water Quality; An Agenda for Agriculture. National Academy Press, Washington, 519p.

NRC (National Research Council). 2000. Clean Coastal Waters. Understanding and reducing the effects of nutrient pollution. National Academy Press, Washington, 405pp.

Nriagu, J.O. 1989. A global assessment of natural sources of atmospheric trace metals. Nature. 338: 47-49.

Nriagu, J.O. \& Pacyna, J.M., 1988. Quantitative assessment of worldwide contamination of air, water and soils by trace metals. Nature. 333: 134-139.

Nunes A.J.P. 2001. Camarões marinhos - Fundamentos da engorda em cativeiro. Panorama da Aqüicultura. 11: 41-49.

Páez-Osuna, F.; Guerrero-Galván, S.R. \& RuizFernández, A.C. 1999. Discharge of nutrients from shrimp farming to coastal waters of the Gulf of California. Mar. Pollut. Bull. 38: 585-592.

Páez-Osuna, F.; Gracia, A.; Flores-Verdugo, F.; LyleFritch, L.P.; Alonso-Rodríguez, R.; Roque, A. \& RuizFernández, A.C. 2003. Shrimp aquaculture and the environment in the Gulf of California ecoregion. Mar. Pollut. Bull. 46: 806-815.

Pedreira, A.J. 1971. Geologia da faixa costeira de Canavieiras e Belmonte, Ilhéus, BA. CEPLAC/ CEPEC, Bol. Téc. 13: 1-15.

Pirrone, N.; Keeler, G.J. \& Nriagu, J.O. 1996. Regional differences in worldwide emissions of mercury to the atmosphere. Atmospheric Environ. 30: 29812987.

Pirrone, N.; Allegrini, I.; Keeler, G.J.; Nriagu, J.O.; Rossmann, R. \& Robbins, J.A. 1998. Historical atmospheric mercury emissions and deposition in North America compared to mercury accumulation in sedimentary records. Atmospheric Environ. 32: 929-940.

Rabalais, N.N. 2002. Changes in Mississippi river nutrient fluxes and consequences for the northern Gulf of 
Mexico coastal ecosystems. In: Lacerda, L.D.; Kremer, H.H.; Kjerfve, B.; Salomons, W.; MarshallCrossland, J.I. \& Crossland, J.C. (ed.) South American Basins: LOICZ Global Change Assessment and Synthesis of River Catchment Coastal Sea Interaction and Human Dimensions. LOICZ Reports \& Studies No. 21, 134-138 pp.

RADAM-BRASIL (Ministério das Minas e Energia, Secretaria Geral). 1981. Projeto RADAMBRASIL: Programa de Integração Nacional - Levantamento de Recursos Naturais, Jaguaribe/Natal, v 23, Rio de Janeiro. Folhas SB 24/25.

Ramalho, J.F.G.P. \& Sobrinho, N.M.B.A. 2001. Metais pesados em solos cultivados com cana-de-açúcar pelo uso de resíduos agroindustriais. Floresta \& Ambiente. 8: 120-129.

Ramalho, J.F.G.P.; Sobrinho, N.M.B.A. \& Velloso, A.C.X. 2001. Contaminação da microbacia de Caetés com metais pesados pelo uso de agroquímicos. Pesq. Agropec. Brasil. 35: 1289-1303.

Rosenberg, R.; Elmgren, R.; Fleischer, S.,; Jansson, P.; Persson, G. \& Dahlin, H. 1990. Marine eutrophication case studies in Sweden. Ambio 19, 102-108.

Schlesinger, W.H. 1997. Biogeochemistry: an Analysis of Global Change. Academic Press, San Diego, $588 p$.

Schlesinger, W.H.; Gray, J.T. \& Gilliam, F.S. 1982. Atmospheric deposition processes and their importance as sources of nutrients in a Chaparral ecosystem of southern California. Wat. Resources Res. 18: 623-629.

SEAGRI (Secretaria de Agricultura, Irrigação e Reforma Agrária do Estado da Bahia), 2003. Cultura da Manga. (SEAGRI), Salvador. www.seagri.ba.gov.br/ Manga.htm (acessado em 01 de 2007)

Sharpley, A.N. \& Syers, J.K. 1979. Phosphorus inputs into a stream draining an agricultural watershed; amounts and relative significance. Wat. Air Soil Pollut. 11: 417-428.

Sharpley, A.N. \& Rekolainen, S. 1997. Phosphorus in agriculture and its environmental implications. In: Phosphorus Loss from Soil to Water. Tunney, $\mathrm{H}$.; Carton, O.T.; Brooker, P.C. \& Johnson, A.E. (ed.), CAB International Press, Cambridge, 1-54 pp.

Sharpley, A.N. \& Tunney, H. 2000. Phosphorus research strategies to meet agricultural and environmental challenges of the $21^{\text {st }}$ century. J. Environ. Qual. 29: 176-181.

Silva, L.F. 1996. Solos Tropicais: Aspectos Pedológicos, Ecológicos e de Manejo. Terra Brasilis Editora, São Paulo, 137p.
Silva, L.F. \& Mendonça, J.R. 1971. Parâmetros fisiográficos interpretativos de solos de tabuleiros do sul da Bahia em fotografias aéreas e imagens de radar. Agrotrópica. 1: 71-74.

Silva, E.C., Silva Filho, A.V., Almeida, M.A.R. 2000. Efeito residual da adubação da batata sobre a produção de matéria seca e exportação de nutrientes do milho verde. Ciência \& Agrotecnologia 24, 509515.

Silva Filho, E.V.; Wasserman, J.C. \& Lacerda, L.D., 1998. History of metal inputs recorded on sediment cores from a remote environment. Ciência \& Cultura 50: 374-376.

Smith, R.A.; Alexander, R.B. \& Wolman, M.G. 1997. Regional interpretation of water monitoring data. Wat. Resources Res. 33: 2781-2798.

Tan, P.A. \& Wong, A.Y.S. 2000. Soluble trace metals and major ionic species in the bulk deposition and atmosphere in Hong Kong. Wat. Air. Soil Pollut. 122: 261-279.

Tappin, A.D. 2002. An examination of the fluxes of nitrogen and phosphorus in temperate and tropical estuaries: Current estimates and uncertainties. Estuarine, Coast. Shelf Sci. 55: 885-901.

Twilley, R.R.; Montaño, M.; Valdivieso, J.M. \& Bodero, A. 1999. The environmental quality of coastal ecosystems in Ecuador: Implications for the development of integrated mangrove and shrimp pond management. In: Yánez-Arancibia, A. \& LaraDomínguez, A.L. (ed.). Mangrove Ecosystems in Tropical America. IUCN/NOAA/Instituto de Ecologia, Xalapa, Mexico, 199-230 pp.

Vaisman A.G. \& Lacerda L.D. 2003. Estimated heavy metal emissions to the atmosphere due to projected changes in the Brazilian energy generation matrix. Reg. Environ. Change 3: 140-145.

Valigura, R.A.; Alexander, R.B.; Brock, D.H.; Castro, H.S.,; Mayers, T.P.; Paerl, H.W.; Stacey, P.E. \& Stanley, D. 2000. An assessment of nitrogen inputs to coastal areas with an atmospheric perspective. American Geophysical Union Coastal Estuaries Series, Washington, 311p.

Vollenweider, R.A. 1968. Scientific Fundamentals of the Eutrophication of Lakes and Flowing Waters, with Particular Reference to Nitrogen and Phosphorus as Factors in Eutrophication. Organization for Economic Co-operation and Development (OECD), Technical Report DAS/CSI/68/27, Paris, 250p.

von Sperling, M. 1996. Introdução a Qualidade das Águas e ao Tratamento de Esgotos. $3^{\circ}$ ed., Departamento de Engenharia Hidráulica e Ambiental, UFMG, Belo Horizonte, 243p. 